\title{
COMMENT
}

\section{A Faustian bargain}

\author{
Gregory A Petsko*
}

\section{An open letter to George M Philip, President of the State University of New York At Albany}

Dear President Philip,

Probably the last thing you need at this moment is someone else from outside your university complaining about your decision. If you want to argue that I can't really understand all aspects of the situation, never having been associated with SUNY Albany, I wouldn't disagree. But I cannot let something like this go by without weighing in. I hope, when I'm through, you will at least understand why.

Just 30 days ago, on October 1st, you announced that the departments of French, Italian, Classics, Russian and Theater Arts were being eliminated. You gave several reasons for your decision, including that 'there are comparatively fewer students enrolled in these degree programs.' Of course, your decision was also, perhaps chiefly, a cost-cutting measure - in fact, you stated that this decision might not have been necessary had the state legislature passed a bill that would have allowed your university to set its own tuition rates. Finally, you asserted that the humanities were a drain on the institution financially, as opposed to the sciences, which bring in money in the form of grants and contracts.

Let's examine these and your other reasons in detail, because I think if one does, it becomes clear that the facts on which they are based have some important aspects that are not covered in your statement. First, the matter of enrollment. I'm sure that relatively few students take classes in these subjects nowadays, just as you say. There wouldn't have been many in my day, either, if universities hadn't required students to take a distribution of courses in many different parts of the academy: humanities, social sciences, the fine arts, the physical and natural sciences, and to attain minimal proficiency in at least one foreign language. You see, the reason that humanities classes have low enrollment is not because students these

*Correspondence: petsko@brandeis.edu

Rosenstiel Basic Medical Sciences Research Center, Brandeis University, Waltham, MA 02454-9110, USA days are clamoring for more relevant courses; it's because administrators like you, and spineless faculty, have stopped setting distribution requirements and started allowing students to choose their own academic programs - something I feel is a complete abrogation of the duty of university faculty as teachers and mentors. You could fix the enrollment problem tomorrow by instituting a mandatory core curriculum that included a wide range of courses.

Young people haven't, for the most part, yet attained the wisdom to have that kind of freedom without making poor decisions. In fact, without wisdom, it's hard for most people. That idea is thrashed out better than anywhere else, I think, in Dostoyevsky's parable of the Grand Inquisitor, which is told in Chapter Five of his great novel, The Brothers Karamazov. In the parable, Christ comes back to earth in Seville at the time of the Spanish Inquisition. He performs several miracles but is arrested by Inquisition leaders and sentenced to be burned at the stake. The Grand Inquisitor visits Him in his cell to tell Him that the Church no longer needs Him. The main portion of the text is the Inquisitor explaining why. The Inquisitor says that Jesus rejected the three temptations of Satan in the desert in favor of freedom, but he believes that Jesus has misjudged human nature. The Inquisitor says that the vast majority of humanity cannot handle freedom. In giving humans the freedom to choose, Christ has doomed humanity to a life of suffering.

That single chapter in a much longer book is one of the great works of modern literature. You would find a lot in it to think about. I'm sure your Russian faculty would love to talk with you about it - if only you had a Russian department, which now, of course, you don't.

Then there's the question of whether the state legislature's inaction gave you no other choice. I'm sure the budgetary problems you have to deal with are serious. They certainly are at Brandeis University, where I work. And we, too, faced critical strategic decisions because our income was no longer enough to meet our expenses. But we eschewed your draconian - and authoritarian solution, and a team of faculty, with input from all parts of the university, came up with a plan to do more with fewer resources. I'm not saying that all the specifics of our solution would fit your institution, but the process sure would have. You did call a town meeting, but it was 
to discuss your plan, not let the university craft its own. And you called that meeting for Friday afternoon on October 1st, when few of your students or faculty would be around to attend. In your defense, you called the timing 'unfortunate', but pleaded that there was a 'limited availability of appropriate large venue options.' I find that rather surprising. If the President of Brandeis needed a lecture hall on short notice, he would get one. I guess you don't have much clout at your university.

It seems to me that the way you went about it couldn't have been more likely to alienate just about everybody on campus. In your position, I would have done everything possible to avoid that. I wouldn't want to end up in the 9th Bolgia (ditch of stone) of the 8th Circle of the Inferno, where the great 14th century Italian poet Dante Alighieri put the sowers of discord. There, as they struggle in that pit for all eternity, a demon continually hacks their limbs apart, just as in life they divided others.

The Inferno is the first book of Dante's Divine Comedy, one of the great works of the human imagination. There's so much to learn from it about human weakness and folly. The faculty in your Italian department would be delighted to introduce you to its many wonders - if only you had an Italian department, which now, of course, you don't.

And do you really think even those faculty and administrators who may applaud your tough-minded stance (partly, I'm sure, in relief that they didn't get the axe themselves) are still going to be on your side in the future? I'm reminded of the fable by Aesop of the Travelers and the Bear: two men were walking together through the woods, when a bear rushed out at them. One of the travelers happened to be in front, and he grabbed the branch of a tree, climbed up, and hid himself in the leaves. The other, being too far behind, threw himself flat down on the ground, with his face in the dust. The bear came up to him, put his muzzle close to the man's ear, and sniffed and sniffed. But at last with a growl the bear slouched off, for bears will not touch dead meat. Then the fellow in the tree came down to his companion, and, laughing, said 'What was it that the bear whispered to you?' 'He told me', said the other man, 'Never to trust a friend who deserts you in a pinch.'

I first learned that fable, and its valuable lesson for life, in a freshman classics course. Aesop is credited with literally hundreds of fables, most of which are equally enjoyable - and enlightening. Your classics faculty would gladly tell you about them, if only you had a Classics department, which now, of course, you don't.

As for the argument that the humanities don't pay their own way, well, I guess that's true, but it seems to me that there's a fallacy in assuming that a university should be run like a business. I'm not saying it shouldn't be managed prudently, but the notion that every part of it needs to be self-supporting is simply at variance with what a university is all about. You seem to value entrepreneurial programs and practical subjects that might generate intellectual property more than you do 'oldfashioned' courses of study. But universities aren't just about discovering and capitalizing on new knowledge; they are also about preserving knowledge from being lost over time, and that requires a financial investment. There is good reason for it: what seems to be archaic today can become vital in the future. I'll give you two examples of that. The first is the science of virology, which in the 1970s was dying out because people felt that infectious diseases were no longer a serious health problem in the developed world and other subjects, such as molecular biology, were much sexier. Then, in the early 1990s, a little problem called AIDS became the world's number 1 health concern. The virus that causes AIDS was first isolated and characterized at the National Institutes of Health in the USA and the Institute Pasteur in France, because these were among the few institutions that still had thriving virology programs. My second example you will probably be more familiar with. Middle Eastern Studies, including the study of foreign languages such as Arabic and Persian, was hardly a hot subject on most campuses in the 1990s. Then came September 11, 2001. Suddenly we realized that we needed a lot more people who understood something about that part of the world, especially its Muslim culture. Those universities that had preserved their Middle Eastern Studies departments, even in the face of declining enrollment, suddenly became very important places. Those that hadn't - well, I'm sure you get the picture.

I know one of your arguments is that not every place should try to do everything. Let other institutions have great programs in classics or theater arts, you say; we will focus on preparing students for jobs in the real world. Well, I hope I've just shown you that the real world is pretty fickle about what it wants. The best way for people to be prepared for the inevitable shock of change is to be as broadly educated as possible, because today's backwater is often tomorrow's hot field. And interdisciplinary research, which is all the rage these days, is only possible if people aren't too narrowly trained. If none of that convinces you, then I'm willing to let you turn your institution into a place that focuses on the practical, but only if you stop calling it a university and yourself the President of one. You see, the word 'university' derives from the Latin 'universitas', meaning 'the whole'. You can't be a university without having a thriving humanities program. You will need to call SUNY Albany a trade school, or perhaps a vocational college, but not a university. Not anymore.

I utterly refuse to believe that you had no alternative. It's your job as President to find ways of solving problems 
that do not require the amputation of healthy limbs. Voltaire said that no problem can withstand the assault of sustained thinking. Voltaire, whose real name was François-Marie Arouet, had a lot of pithy, witty and brilliant things to say (my favorite is 'God is a comedian playing to an audience that is afraid to laugh'). Much of what he wrote would be very useful to you. I'm sure the faculty in your French department would be happy to introduce you to his writings, if only you had a French department, which now, of course, you don't.

I guess I shouldn't be surprised that you have trouble understanding the importance of maintaining programs in unglamorous or even seemingly 'dead' subjects. From your biography, you don't actually have a PhD or other high degree, and have never really taught or done research at a university. Perhaps my own background will interest you. I started out as a classics major. I'm now Professor of Biochemistry and Chemistry. Of all the courses I took in college and graduate school, the ones that have benefited me the most in my career as a scientist are the courses in classics, art history, sociology, and English literature. These courses didn't just give me a much better appreciation for my own culture; they taught me how to think, to analyze, and to write clearly. None of my sciences courses did any of that.

One of the things I do now is write a monthly column on science and society. I've done it for over 10 years, and I'm pleased to say some people seem to like it. If I've been fortunate enough to come up with a few insightful observations, I can assure you they are entirely due to my background in the humanities and my love of the arts.

One of the things I've written about is the way genomics is changing the world we live in. Our ability to manipulate the human genome is going to pose some very difficult questions for humanity in the next few decades, including the question of just what it means to be human. That isn't a question for science alone; it's a question that must be answered with input from every sphere of human thought, including - especially including the humanities and arts. Science unleavened by the human heart and the human spirit is sterile, cold, and self-absorbed. It's also unimaginative: some of my best ideas as a scientist have come from thinking and reading about things that have, superficially, nothing to do with science. If I'm right that what it means to be human is going to be one of the central issues of our time, then universities that are best equipped to deal with it, in all its many facets, will be the most important institutions of higher learning in the future. You've just ensured that yours won't be one of them.

Some of your defenders have asserted that this is all a brilliant ploy on your part - a master political move designed to shock the legislature and force them to give SUNY Albany enough resources to keep these departments open. That would be Machiavellian (another notable Italian writer, but then, you don't have any Italian faculty to tell you about him), certainly, but I doubt that you're that clever. If you were, you would have held that town meeting when the whole university could have been present, at a place where the press would be all over it. That's how you force the hand of a bunch of politicians. You proclaim your action on the steps of the state capitol. You don't try to sneak it through in the dead of night, when your institution has its back turned.

No, I think you were simply trying to balance your budget at the expense of what you believe to be weak, outdated and powerless departments. I think you will find, in time, that you made a Faustian bargain. Faust is the title character in a play by Johann Wolfgang von Goethe. It was written around 1800 but still attracts the largest audiences of any play in Germany whenever it's performed. Faust is the story of a scholar who makes a deal with the devil. The devil promises him anything he wants as long as he lives. In return, the devil will get well, I'm sure you can guess how these sorts of deals usually go. If only you had a Theater department, which now, of course, you don't, you could ask them to perform the play so you could see what happens. It's awfully relevant to your situation. You see, Goethe believed that it profits a man nothing to give up his soul for the whole world. That's the whole world, President Philip, not just a balanced budget. Although, I guess, to be fair, you haven't given up your soul. Just the soul of your institution.

Disrespectfully yours,

\section{Gregory A Petsko}

Published: 31 October 2010

doi:10.1186/gb-2010-11-10-138

Cite this article as: Petsko GA: A Faustian bargain. Genome Biology 2010, 11:138. 